\author{
PIOTR L. WILCZYŃSKI \\ Uniwersytet Pedagogiczny w Krakowie, Polska \\ Pedagogical University of Cracow, Poland
}

\title{
Układy przestrzenne wielkich kompleksów zbrojeniowych Europy
}

\section{Space Management at Great Arms and Military Equipment Factories in Europe}

\begin{abstract}
Streszczenie: W artykule przedstawione zostało rozmieszczenie największych zakładów zbrojeniowych w Europie, a także specyfika ich zagospodarowania przestrzennego. Celem jest znalezienie różnic i podobieństw między zakładami w tej branży. Biorąc pod uwagę specyfikę każdego z nich, podjęto próbę odnalezienia cech wspólnych. Analiza dokonana została poprzez porównanie zdjęć satelitarnych przedstawiających rozmieszczenie poszczególnych elementów danych kompleksów. Ze względu na ograniczenie objętościowe do analizy wybrane zostały cztery największe zakłady działające w poszczególnych gałęziach branży: stoczniowej, lotniczej, pancerno-zmechanizowanej oraz strzeleckiej. Wyniki odzwierciedlają współczesną rolę przemysłu zbrojeniowego w kształtowaniu układów przestrzennych miast, w których działają te zakłady. Temu poświęcono ostatnią część artykułu. Wynikające wnioski, uwagi, konkluzje przedstawiono w zakończeniu. Zawierają one również porównanie z największymi polskimi kompleksami zbrojeniowymi, dużo mniejszymi w stosunku do największych firm w Europie. Pozwoliło to na stwierdzenie, czy rozwój polskich ośrodków zbrojeniowych jest, czy też nie, blokowany poprzez uwarunkowania geograficzne i przestrzenne.
\end{abstract}

Abstract: The article describes the distribution of the biggest arms and military equipment factories in Europe. Spatial management special problems of these military complexes are also revealed. The aim of this paper is to find any differences and similarities between military equipment factories. To do that, research was conducted based on an analysis of satellite images of different elements of military complexes. Four biggest complexes in each branch were taken into account - from rifling industry, armor-mechanized weapons industry, naval shipyards, and military aviation factories. The results show the role of military industrial complexes in spatial development of towns in which they exist. The last section of this paper is dedicated to this topic. Conclusions also include the comparison between the biggest European military industrial complexes and the industry in a medium-sized country such as Poland. It allowed to conclude the main factors blocking any development of Polish military industrial complexes. Are they rather geographical, political or economical - the probable solution is in the conclusion.

Słowa kluczowe: baza wojskowa; broń; geografia wojskowa; kompleks zbrojeniowy; przemysł zbrojeniowy; rozwój miast; zagospodarowanie przestrzenne

Keywords: armament; Defense Industrial Complex; military geography; Military Industrial Complex; spatial management; town spatial development; weaponry 
Otrzymano: 17 stycznia 2017

Received: 17 January 2017

Zaakceptowano: 4 sierpnia 2017

Accepted: 4 August 2017

\section{Sugerowana cytacja / Suggested citation:}

Wilczyński, P.L. (2017). Układy przestrzenne wielkich kompleksów zbrojeniowych Europy. Prace Komisji Geografii Przemysłu Polskiego Towarzystwa Geograficznego, 31(4), 103-119. https://doi. org/10.24917/20801653.314.7

\section{WSTĘP}

Niniejszy artykuł, którego przedmiotem są kompleksy zbrojeniowe Europy, ze względu na ograniczenia objętościowe został okrojony do przedstawienia map rozmieszczenia poszczególnych gałęzi przemysłu zbrojeniowego w Europie. Dane do przedstawienia informacji na tych mapach zebrane zostały $w$ ciągu ostatnich lat $\mathrm{z}$ baz danych wynikających z umów międzynarodowych o przejrzystości międzynarodowego obrotu bronią. Najczęściej korzystano z baz znajdujących się na serwerach Sztokholmskiego Instytutu Badań nad Pokojem (SIPRI, 2017, 17 stycznia). Przedstawiają one w większości informacje najaktualniejsze, czyli sprzed dwóch lub trzech lat.

Druga część artykułu zawiera podstawowe informacje na temat czterech największych zakładów zbrojeniowych w Europie, po jednym z każdej z następujących gałęzi: strzeleckiej, pancerno-zmechanizowanej, stoczniowej i lotniczej. Przegląd ten i wybór również uwarunkowany jest ograniczeniem objętościowym artykułu, ale w stopniu wystarczającym uwzględnienia aspekty przestrzenne, jak bowiem pokazują bardziej wnikliwe badania, kompleksy zbrojeniowe mają dość duże podobieństwa w poszczególnych gałęziach (Freedman, 2014; Harris, 2014; Furgacz, 2015) oraz bardzo wiele powiązań między sobą. Oprócz map rozmieszczenia poszczególnych zakładów i kompleksów ta zasadnicza część przedstawia zdjęcia satelitarne czterech fabryk produkujących broń. Zdjęcia te poddano dalej analizie, a jej wyniki przedstawione są we wnioskach. Zwrócono tam też uwagę na skutki obecności przemysłu zbrojeniowego w miejscowościach, w których działają, a w szczególności dla ich rozwoju układu przestrzennego.

Celem tego artykułu jest przegląd ośrodków przemysłu zbrojeniowego, a także przedstawienie zbiorczych map, na których oznaczono, gdzie aktualnie produkuje się nową broń. Mapy nie zawierają zakładów remontowych lub produkujących części albo samą amunicję. Celem jest tu również pokazanie podobieństw i różnic między kompleksami zbrojeniowymi względem zagospodarowania przestrzennego miast i względem siebie nawzajem oraz w zależności od państw, w których działają. Do realizacji tego celu zastosowano analizę porównawczą zdjęć satelitarnych wspomaganą wynikami wcześniejszych badań. Zakres czasowy jest bieżący, a terytorialny został ograniczony do Europy, bez Rosji i Turcji, których większość terytorium znajduje się w Azji.

\section{ZAGADNIENIE KOMPLEKSU ZBROJENIOWEGO W NAUCE}

Pojęcie kompleksu przemysłu zbrojeniowego zostało na zachodzie wprowadzone przez byłego prezydenta USA D. Eisenhowera w latach sześćdziesiątych, jako odpowiedź na konglomerację zbrojeń w państwach socjalistycznych (Albertson, 1963). Proces łączenia interesów państwa, wojska i przemysłu doprowadził do tego, że w okresie zimnej 
wojny rozbudowane zostały wielkie korporacje w krajach NATO, które istnieją do dziś. Kompleksy przemysłu zbrojeniowego uzyskały osobny status, tak jak w państwach socjalistycznych (nazywane były: MIC - Military Industrial Complex). Utworzono zatem koalicję wspólnych interesów łączących niektórych członków sił zbrojnych (Balcerowicz, 2006), członków biurokracji ministerstw obrony oraz finansów, a także legislatury oraz członków-właścicieli fabryk mogących rozpocząć produkcję zbrojeniową wraz $\mathrm{z}$ robotnikami tych fabryk. W efekcie istnienia tej koalicji interesów z czasem doszło do rozwoju zjawiska budowy specjalnych kompleksów zbrojeniowych, które w latach sześćdziesiątych nazwano MIC.

Większość rozważań teoretycznych nad MIC zdaje się potwierdzać, że na zachodzie mają one rodowód zimnowojenny, zaś w państwach socjalistycznych związane są z funkcjonowaniem gospodarki centralnie planowanej, czyli w większości państw również jest to rodowód zimnowojenny, poza ZSRR i jej spadkobiercami. Okres zimnej wojny służył rozwojowi wielkich kompleksów zbrojeniowych. Stały stan napięcia pomiędzy potęgami, który nie eskalował do „gorącej wojny” i sprawdzenia potęgi adwersarza empirycznie, usprawiedliwiał stałe i znaczne nakłady na tę dziedzinę gospodarki (Żukrowska, 1989). Dlatego od końca zimnej wojny nastąpiły znaczne zmiany w zachodniej myśli gospodarczej dotyczącej MIC. Kraje te nie musiały już produkować tak dużych ilości uzbrojenia i przestały otrzymywać aż tak duże nakłady budżetowe jak wcześniej. Na wschodzie zaś wiele z tych kompleksów upadło w wyniku bankructwa lub przejęć przez sektor prywatny i cywilny. W międzyczasie rosły także koszty związane z badaniami nad nowoczesnymi technologiami i ich rozwojem. Te trendy oraz transformacje w światowej polityce i gospodarce doprowadziły do zmian dotychczasowych relacji między państwem, siłami zbrojnymi i przemysłem. Nie oznaczało to jednak upadku MIC na świecie i straty przez ten sektor gospodarki wpływów politycznych i gospodarczych (Wilczyński, 2013b).

Ekonomiści głównego nurtu (szkoły Keynesa), analizując gospodarkę, zwykle uważali istnienie MIC jako anomalię. Ekonomiści neoklasyczni zaś brali częściej pod uwagę interes i potrzebę państwa, które ma zapewniać bezpieczeństwo. Dlatego alokacja kapitału w MIC jest funkcją podobną do inwestowania w ubezpieczenia. MIC stanowią zatem w ekonomii neoklasycznej najskuteczniejszą formę alokacji środków w zaspokojenie potrzeby bezpieczeństwa (Hartley, Sandler, 1995). Większość badań nad MIC toczy się obecnie w USA. Ukonstytuowanie, mechanizmy gospodarcze, zarządzanie MIC w Europie rządzi się jednak troszkę innymi prawami, gdyż większa jest tu ingerencja państwa w gospodarkę, wyższy jest też - w zależności od państw - poziom upaństwowienia sektora zbrojeniowego. Rynki zbytu w Europie są też znacznie mniejsze, a często zdominowane przez kapitał zagraniczny (Lovering, 1990; Dunne, 1995).

Przegląd koncepcji dotyczących kompleksów zbrojeniowych ukazuje brak ugruntowanego i powszechnie zaakceptowanego modelu teoretycznego. Różnią się one w zależności od regionu świata, jak i dominującej w danym kraju szkoły ekonomicznej (keynesowska, marksistowska i neoklasyczna). Koncepcje te mają też raczej wartość deskryptywną niż analityczną. Badania struktury funkcjonalnej MIC również wskazują na istnienie - $\mathrm{w}$ różnym stopniu - koalicji interesów w poszczególnych krajach, lecz wyraźnie pokazują zróżnicowanie w zależności od badanego państwa. Ostatecznie można przyjąć definicję, jaką na podstawie swoich badań przedłożył B. Fine (1993), że MIC to zespół obiektów przemysłowych wykorzystujący granty budżetowe państwa na 
obronność. Dodać można, że w państwach socjalistycznych powstanie MIC było efektem centralizacji gospodarki, a następnie jej restrukturyzacji w latach dziewięćdziesiątych (Hercik, Szczyrba, 2012), zaś na zachodzie efektem rywalizacji zimnowojennej.

W skład MIC wchodzą różne elementy, które wyróżniają je od pozostałych obiektów przemysłowych:

- znajdują się na terenie wojskowym,

- zawierają dział R\&D,

- rozwinęły się w okresie zimnej wojny, gdy szykowano się do gorącej wojny i ścigano się w wydatkach na zbrojenia,

- łączą świat wojska, biznesu i polityki oraz administracji,

- zawierają DIB - Defense Industrial Base (np. poligony doświadczalne, magazyny, infrastrukturę krytyczną) (Smith, 1977; Dunne, 1995).

Ponadto badania własne autora, które prowadziły do wykonania niżej przedstawionych opracowań dotyczących przemysłu zbrojeniowego w Europie i jego rozmieszczenia, pozwoliły na wyróżnienie trzech głównych typów MIC w naszym regionie. Na zachodzie dominują wciąż wielkie międzynarodowe korporacje zbrojeniowe i to one są głównym odbiorcą wydatków budżetowych państw na obronność. Po wschodniej stronie dawnej „żelaznej kurtyny” dominują przedsiębiorstwa państwowe, często niedofinansowane i źle zarządzane i nierentowne. Tak zwane państwowe „molochy” tego typu stopniowo znikają z mapy Europy, a ich produkcję przejmuje pierwszy rodzaj MIC. Trzeci rodzaj MIC stanowią mniejsze przedsiębiorstwa, których produkcja w głównej mierze skierowana jest na rynek cywilny i tylko okazyjnie otrzymują one zlecenia lub wygrywają przetargi na konstrukcje i realizację zapotrzebowania armii. Dominują one w państwach neutralnych w czasie zimnej wojny (np. Szwecja, Szwajcaria) (Wilczyński, 2015a).

Ryc. 1. Aktywne linie produkcyjne w przemyśle zbrojeniowym na świecie w 2011 roku

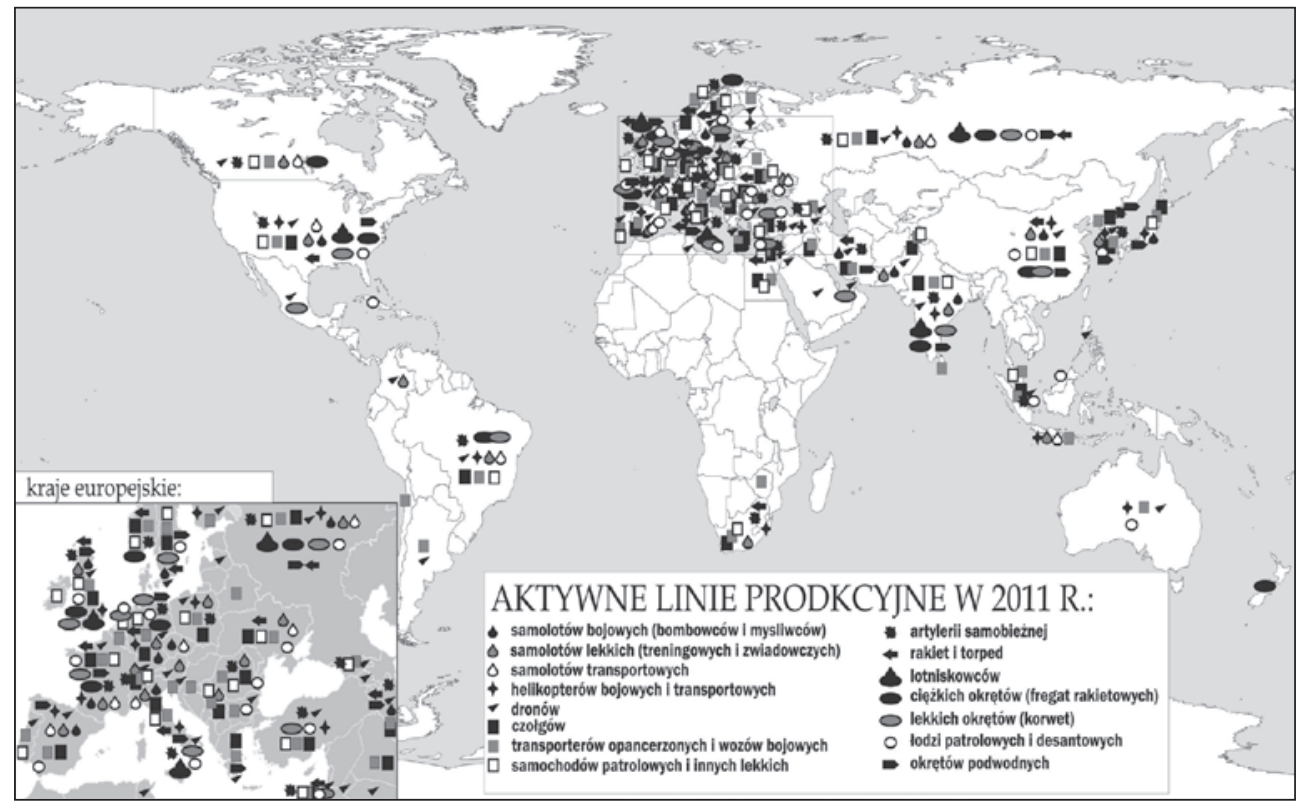

Źródło: Wilczyński (2012) 
Zróżnicowane jest także zaangażowanie państw na świecie $\mathrm{w}$ produkcję w MIC w różnych gałęziach przemysłu zbrojeniowego. Wielkie mocarstwa, takie jak USA, Rosja i Chiny, oraz część państw Europy posiadają każdą gałąź przemysłu zbrojeniowego rozwiniętą, co jest efektem ich mocarstwowych ambicji i polityki. Mocarstwa regionalne, takie jak wiele państw europejskich, Brazylia, Indie, Japonia, Turcja, Iran, Pakistan, Kanada, również posiadają wiele rozwiniętych gałęzi, ale nie posiadają każdej z możliwych. Mniejsze lub biedniejsze państwa nie posiadają MIC i rzadziej rozwijają własną produkcję zbrojeniową (ryc. 1).

\section{ROZMIESZCZENIE PRODUKCJI ZBROJENIOWEJ W EUROPIE - BROŃ STRZELECKA}

Rozwój technologiczny w przemyśle zbrojeniowym od lat skupia się głównie na broni ciężkiej. Rozwijane są systemy rakietowe, technologie kosmiczne, awiacyjne i komputerowe. Głównie na to idą nakłady w rozwoju technologii zbrojeniowych, co zresztą

Ryc. 2. Fabryki broni strzeleckiej w Europie w 2014 roku

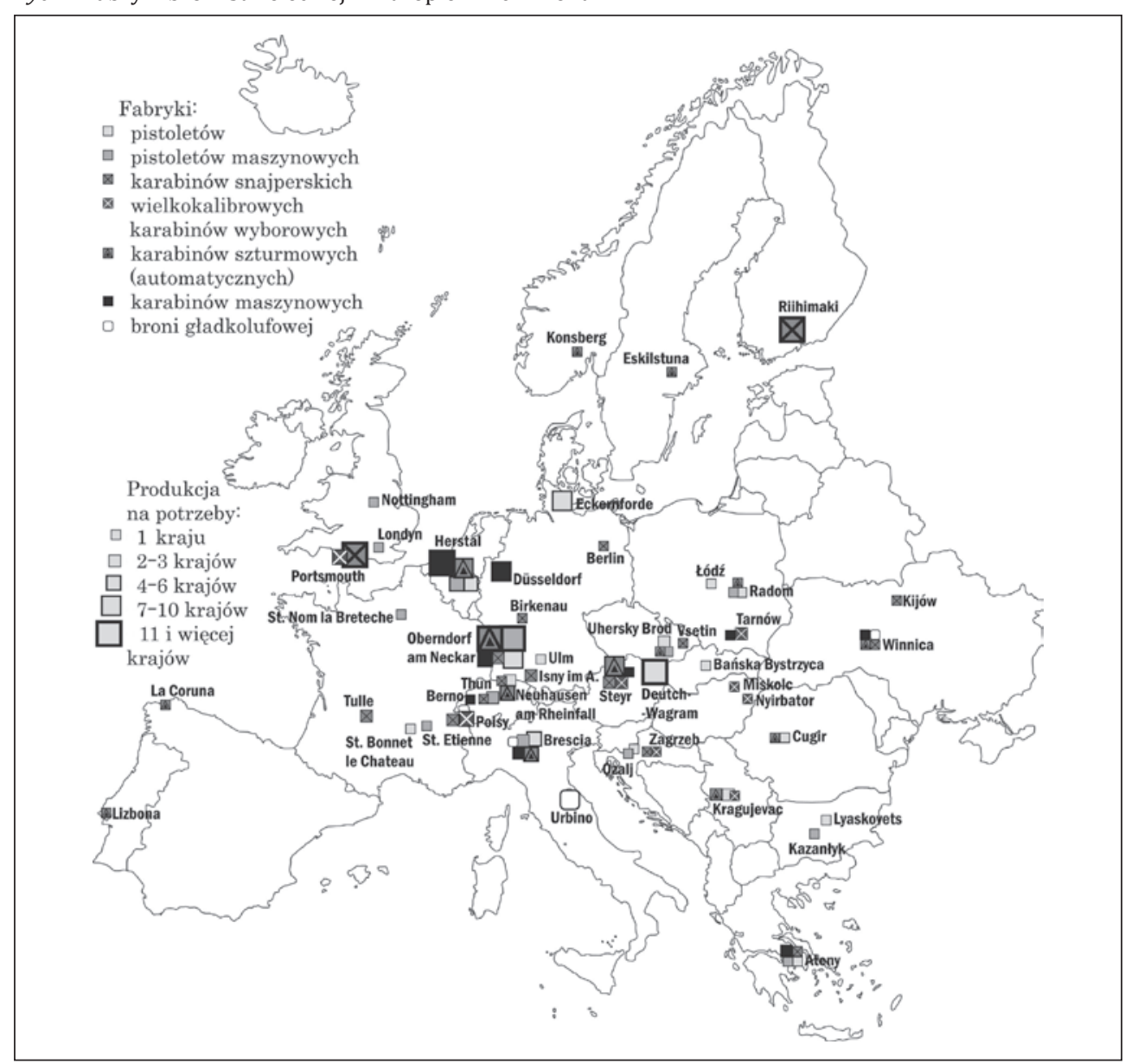

Źródło: Wilczyński (2015b) 
było już wcześniej ukazane (Wilczyński, 2012). Również w czasie kryzysów priorytetem jest badanie i rozwój technologii wielofunkcyjnych, które mają zwiększyć nie tylko osiągi i skuteczność uzbrojenia, ale mają także znaczenie i popyt na rynku cywilnym (Wilczyński, 2013a).

Broń lekka, strzelecka, dzieli się na kilka głównych segmentów. Asortyment broni można podzielić na broń produkowaną do celów bojowych oraz pozostałych, których odbiorcą jest głównie środowisko cywilne. Broń bojowa w zależności od kalibru i budowy oraz celu użycia w swym asortymencie można podzielić na: pistolety, pistolety maszynowe, karabiny snajperskie (wyborowe), wielkokalibrowe karabiny wyborowe, karabinki szturmowe (RKM, automaty), karabiny maszynowe, strzelby gładkolufowe (Woźniak, 2001-2002). Każdy z tych rodzajów broni ma inne zalety i przez to używa się go w innym środowisku walki. Fabryki w Europie specjalizują się w jednym typie broni bojowej bądź w wielu. Ryc. 2 przedstawia ich rozmieszczenie.

Największą fabryką jest kompleks zbrojeniowy w Niemczech w Oberndorf am Neckar, należący do korporacji Heckler \& Koch (HK). W Wielkiej Brytanii największą firmą jest Accuracy International (AI), której ośrodek produkcji znajduje się w Portsmouth. Dobrze rozwiniętą produkcję ma także Belgia w zakładach w Herstal, należących do Fabrique Nationale (FN). Włoskie zakłady w Brescii należą do firmy Fabarm. Neutralna Austria posiada rozbudowane zakłady broni strzeleckiej w Steyr, należące do firmy o tej samej nazwie, i największą fabrykę pistoletów w Europie marki Glock w Deutsh-Wagram.

\section{ROZMIESZCZENIE PRODUKCJI ZBROJENIOWEJ W EUROPIE - BROŃ PANCERNA I ZMECHANIZOWANA}

Broń ciężka, używana w bitwach lądowych, to często klucz do zwiększenia siły ognia, mobilności i odporności na pociski, a zatem i do zwycięstwa, jak uważa większość współczesnych strategów. Wśród tej broni najważniejsza rolę odgrywają czołgi. Obecnie w krajach europejskich zaprzestano ich produkcji, gdyż jest ona kosztowna i wymaga olbrzymich nakładów na badania i rozwój, który mógłby zrekompensować inwestycje wielkich mocarstw w nowoczesną broń pancerną. Obecnie najlepszym czołgiem na świecie jest rosyjski czołg T-14 Armata. Przewyższa on swoimi osiągami każdą amerykańską i europejską konstrukcję (Holota, Kurpas, 2016).

W Europie tylko siedem państw posiada czynne linie produkcyjne czołgów. Niemcy, Hiszpania i Grecja produkują czołgi Leopard 2, których licencjodawcą jest największy producent broni pancernej i zmechanizowanej w Europie, korporacja Rheinmetall (2017, 17 stycznia) z siedzibą w Duesseldorfie. Francja produkuje czołgi najdrożej na świecie, przez co nie są one tak chętnie kupowane za granicą. Korporacja AMX powoli przygotowuje się do wprowadzenia nowego prototypu, lecz musi sprzedać swoje czołgi Leclerc. Do pozostałych producentów należą Włosi z czołgami C1 Ariete, Szwedzi z czołgami Stridvagn 122 i Ukraina z najtańszymi w Europie czołgami T-84 Opłot, które jednak są niższej klasy niż wcześniej wymienione (ryc. 3).

Wsparciem dla czołgów są na polu walki bojowe wozy piechoty (BWP), czyli pojazdy gąsienicowe z lżejszym opancerzeniem i uzbrojeniem, jednak potrafiące przewieźć desant piechoty. W Europie tylko sześć państw produkuje BWP, ale niektóre po kilka rodzajów (ryc. 4). Najwyższe notowania mają brytyjskie pojazdy FV Warrior, a także niemieckie Mardery. Niemcy produkują również SPz Puma oraz lekkie czołgi (tankietki) Wiesel AWC, będące konstrukcją pośrednią między czołgiem a BWP. Francja używa 
Ryc. 3. Kraje produkujące czołgi w Europie

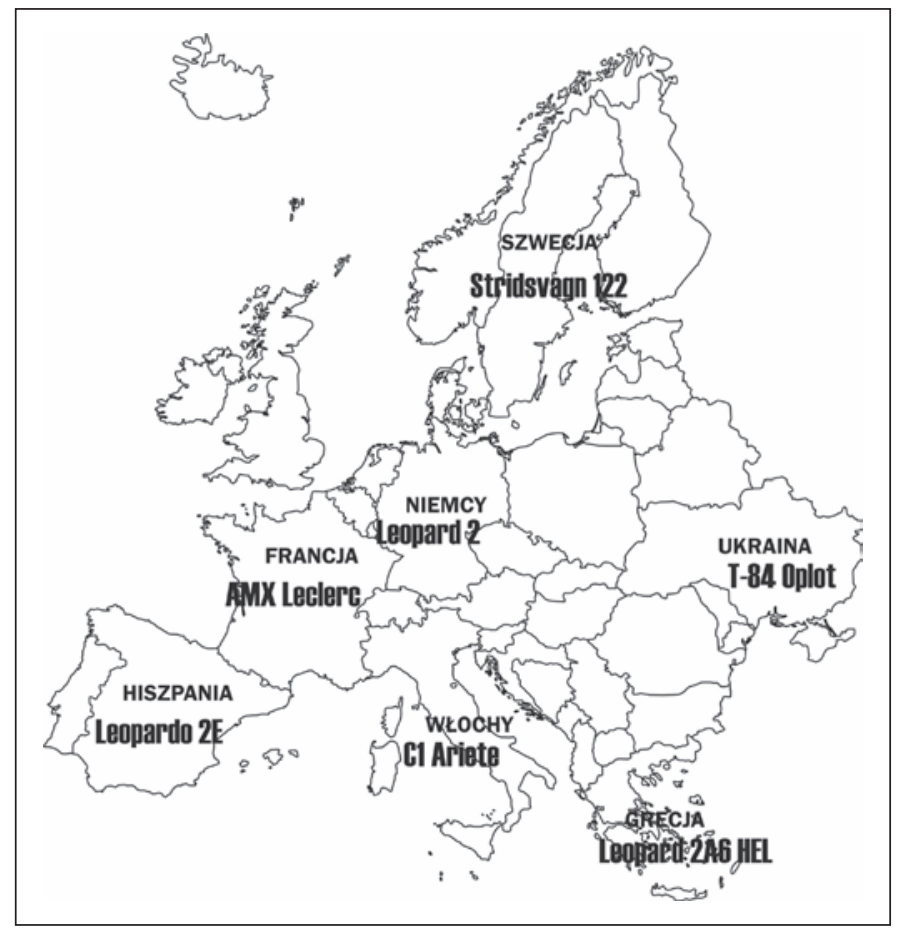

Źródło: Wilczyński (2016)

swoich BWP o nazwie VBCI, a Włochy produkują zarówno Dardo, jak i Freccię. Do producentów BWP należy także Szwecja, specjalizująca się w budowie BWP przystosowanych do działań w trudnych warunkach terenowych i klimatycznych - Strf 90/CV 9030, a także Rumunia, budująca zmodernizowaną wersję sowieckiego sprzętu, czyli MLI-84 (ryc. 4).

Kolejnym rodzajem broni są kołowe transportery opancerzone (KTO). Nie różnią się one wiele od BWP, poza napędem przełożonym nie na gąsienice, lecz na koła obwiedzione oponami jak pojazdy szosowe, przez co są łatwiejsze w utrzymaniu, lecz gorzej radzą sobie w trudnym terenie. KTO produkowane są obecnie w Europie w znacznie większej skali niż BWP. Z dumą możemy stwierdzić, że polski produkt - KTO Rosomak - należy do czołówki najlepszych pojazdów tego typu. Łącznie 13 państw w Europie produkuje kołowe transportery opancerzone (ryc. 5).

W Europie również są produkowane lżejsze pojazdy na potrzeby wojska: ciężarówki, samochody terenowe, motocykle, quady, pojazdy specjalistyczne. Do głównych producentów lżejszego sprzętu należą brytyjskie firmy Leyland, Alvis-Unipower, Land Rover, Supacat, JCB i BAE Systems, niemieckie - MAN, Mercedes-Benz, Volkswagen, Rheinmetall, KMW, holenderskie - DAF, DDVS i GEMCO MS (Jankowski, 2011), francuskie - Renault oraz Nexter, Panhard i LOHR, hiszpańska - Urovesa, portugalska - UMM, szwajcarska - Mowag, włoskie - Fiat i Iveco, czeska - Tatra, polskie Obrum, FS Honker, WZŁ i AMZ Kutno, ukraińskie - KrAZ i fabryka maszyn im. Morozowa w Charkowie, szwedzkie - Volvo i Scania oraz fińskie - Sisu. Mniejsi producenci znajdują się także na Słowacji, Węgrzech, w Serbii i Grecji (Wilczyński, 2016). 
Ryc. 4. Kraje produkujące BWP w Europie

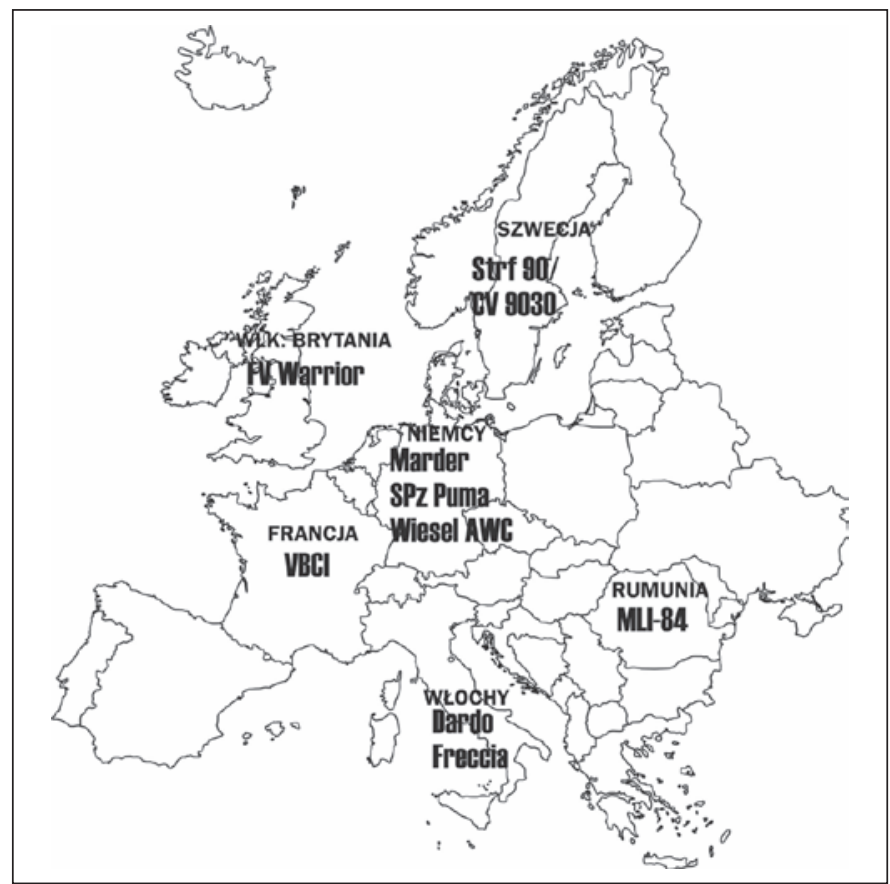

Źródło: Wilczyński (2016)

Ryc. 5. Kraje produkujące KTO w Europie

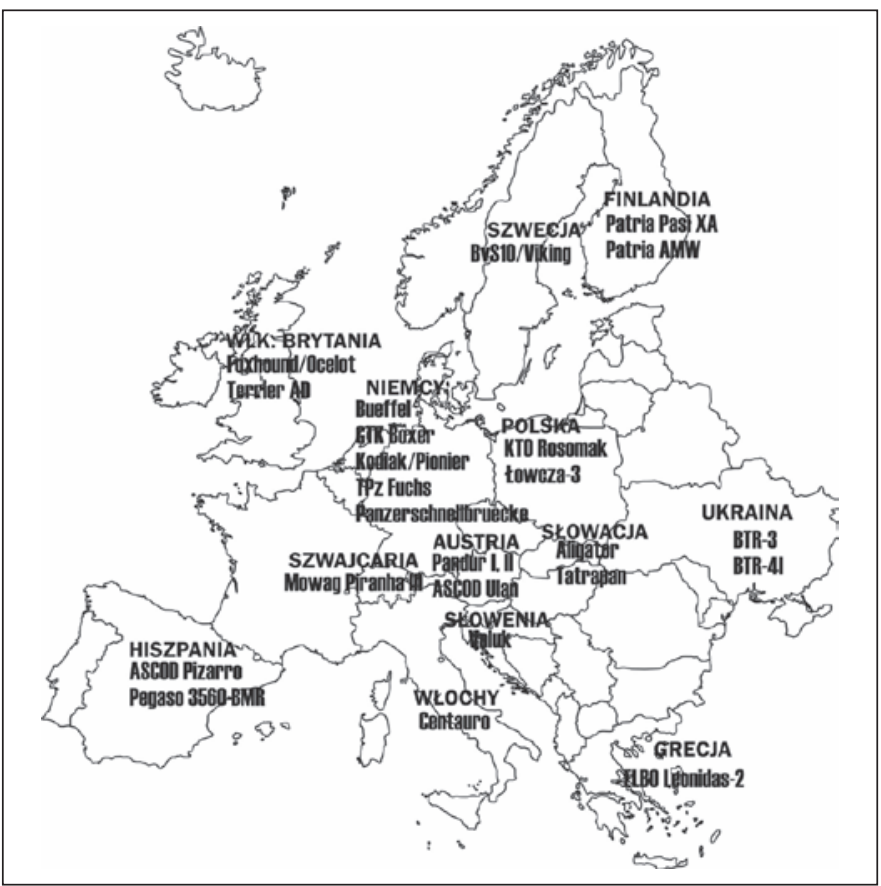

Źródło: Wilczyński (2016) 


\section{ROZMIESZCZENIE PRODUKCJI ZBROJENIOWEJ W EUROPIE - STOCZNIE WOJENNE}

Stocznie zaopatrujące marynarki wojenne oczywiście rozmieszczone są wzdłuż wybrzeży morskich. Oprócz tego uwarunkowania w zasadzie nic większego je nie różni od innych kompleksów zbrojeniowych. Niemal każde nadmorskie państwo posiada choćby najmniejszą stocznię, w której buduje okręty wojenne, co jest istotne ze względu na wrażliwość wobec ewentualnej blokady portów w czasie działań zbrojnych. Poza tym funkcją marynarki jest także wykonywanie misji ratunkowych na morzu oraz zwalczanie kontrabandy i piractwa, czyli ochrona szlaków handlowych. Największą stocznią w Europie, która wyprodukowała najwięcej aktywnych obecnie (stan na 2014 rok) okrętów wojennych, jest hiszpańska stocznia należąca do państwowej firmy Navantia w galicyjskim mieście Ferrol (Wilczyński, 2015c). Konkuruje ona głównie z niemiecką stocznią w Kilonii, specjalizującą się w budowie konwencjonalnych okrętów podwodnych, oraz włoską stocznią w La Spezii, budującą przeważnie trałowce. Stocznia w Ferrol w odróżnieniu od nich buduje prawie każdy rodzaj okrętów (ryc. 6).

Ryc. 6. Stocznie produkujące okręty wojenne w Europie

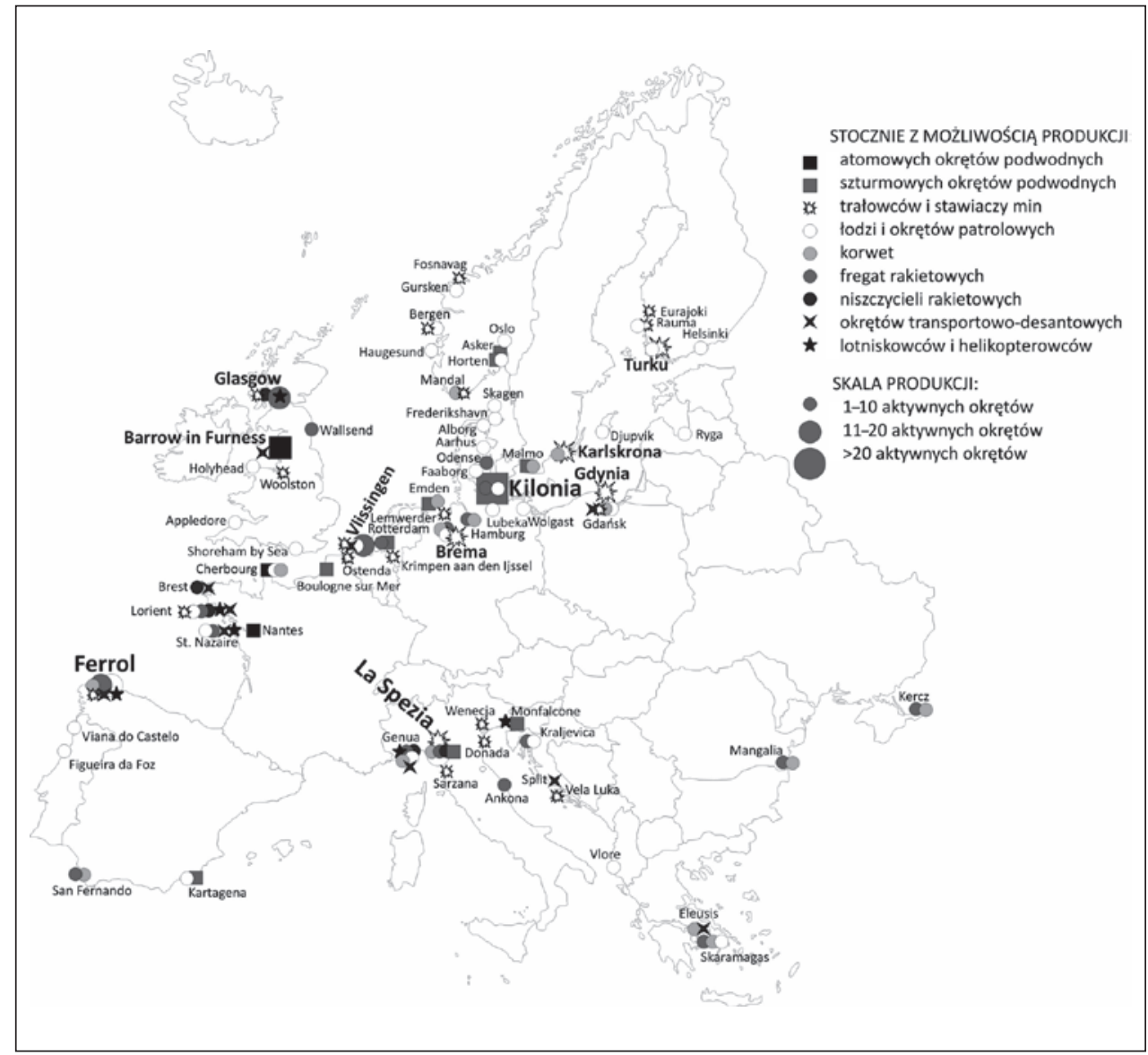

Źródło: Wilczyński (2015c) 


\section{ROZMIESZCZENIE PRODUKCJI ZBROJENIOWEJ W EUROPIE - ZAKŁADY LOTNICZE}

Najwięcej samolotów bojowych w Europie produkowanych jest w jej zachodniej części. Największym producentem samolotów bojowych różnego rodzaju jest brytyjska korporacja BAE Systems (2017, 17 stycznia), której dział zajmujący się produkcją wojskową i lotniczą znajduje się w Warton, na północ od Liverpoolu. Duże znaczenie w produkcji zbrojeniowej w lotnictwie mają kraje współpracujące w ramach EADS: Niemcy, Francja, Hiszpania i Włochy. Mniejsze, ale również istotne, znaczenie mają Szwecja i Ukraina. Poza tym produkcja w mniejszych ilościach odbywa się także w Polsce, Czechach, Rumunii, Austrii, Szwajcarii i Serbii (ryc. 7).

\section{UKŁADY PRZESTRZENNE PRZEDSIĘBIORSTW ZBROJENIOWYCH}

Ze względu na ograniczenia objętościowe, do analizy wybrano MIC czterech największych przedsiębiorstw, po jednym z każdej branży: strzeleckiej, pancerno-zmechanizowanej, stoczniowej i lotniczej. Największym przedsiębiorstwem działającym w Europie w gałęzi strzeleckiej jest niemiecka firma Heckler\&Koch z siedzibą w Oberndorf am Neckar. Firma produkuje każdy rodzaj broni strzeleckiej, której bardzo duża część opuszcza Niemcy i jest eksportowana do bardzo wielu krajów świata. Oprócz broni $\mathrm{H} \& \mathrm{~K}$ produkuje różne narzędzia oraz broń do celów innych niż wojskowe. Jako korporacja międzynarodowa H\&K posiada fabryki także w USA, Wielkiej Brytanii, Francji i Indonezji. Fabryka w Oberndorfie jest jednak wciąż największym obiektem produkcyjnym H\&K (ryc. 8).

Układ przestrzenny zakładów H\&K obejmuje sporą część miasteczka. Od północy i zachodu okala je obwodnica miasta. W południowej części znajdują się magazyny i bocznica kolejowa łącząca z siecią transportową i poligonem wojskowym. Na zachód od nich położona jest strzelnica, gdzie testuje się broń. Środkową część obejmują parkingi, kolejne magazyny, fabryka amunicji, a także kryta strzelnica. Nieco dalej na północ jest główny gmach firmy z biurami. Zakłady produkcyjne zaś położone są we wschodniej części kompleksu, który otoczony jest drutem kolczastym i strzeżony.

Największą firmą produkującą czołgi jest Rheinmetall Defense, która posiada kilkanaście zakładów w Niemczech i w wielu innych państwach. Na potrzeby niniejszego artykułu została wybrana jednak tylko jedna fabryka, gdzie produkuje się czołgi Leopard 2. Znajduje się ona w Unterluess (ryc. 9). Rheinmetall produkuje ponad 1500 produktów zarówno na rynek cywilny, jak i wojskowy, oraz posiada wiele spółek-córek rozsianych po świecie: w USA, Kanadzie, Niemczech, Wlk. Brytanii, Holandii, Szwajcarii, Austrii, Włoszech, Polsce, Szwecji, Norwegii, RPA, Arabii Saudyjskiej, Zjednoczonych Emiratach Arabskich, Rosji, Singapurze, Malezji i Australii.

Zagospodarowanie kompleksu zbrojeniowego w Unterluess uwzględnia rolę, jaką odgrywa ta fabryka w systemie korporacji Rheinmetall, gdzie wiele podzespołów przywozi się już gotowych do montażu. Dlatego nie powinien dziwić mały rozmiar kompleksu. Położony z dala od miasteczka, w lesie, w bezpośrednim sąsiedztwie bazy wojskowej znajdującej się na wschód od fabryk, kompleks połączony jest od północy bocznicą kolejową, za którą znajduje się poligon. W samym centrum kompleksu rozmieszczono główną halę produkcyjną, a po obu jej stronach stosunkowo niewielkie magazyny. Za nimi znajduje się montownia podwozi gąsienicowych i dźwig ładujący czołgi na 
Ryc. 7. Rozmieszczenie produkcji samolotów wojskowych w Europie w 2013 roku

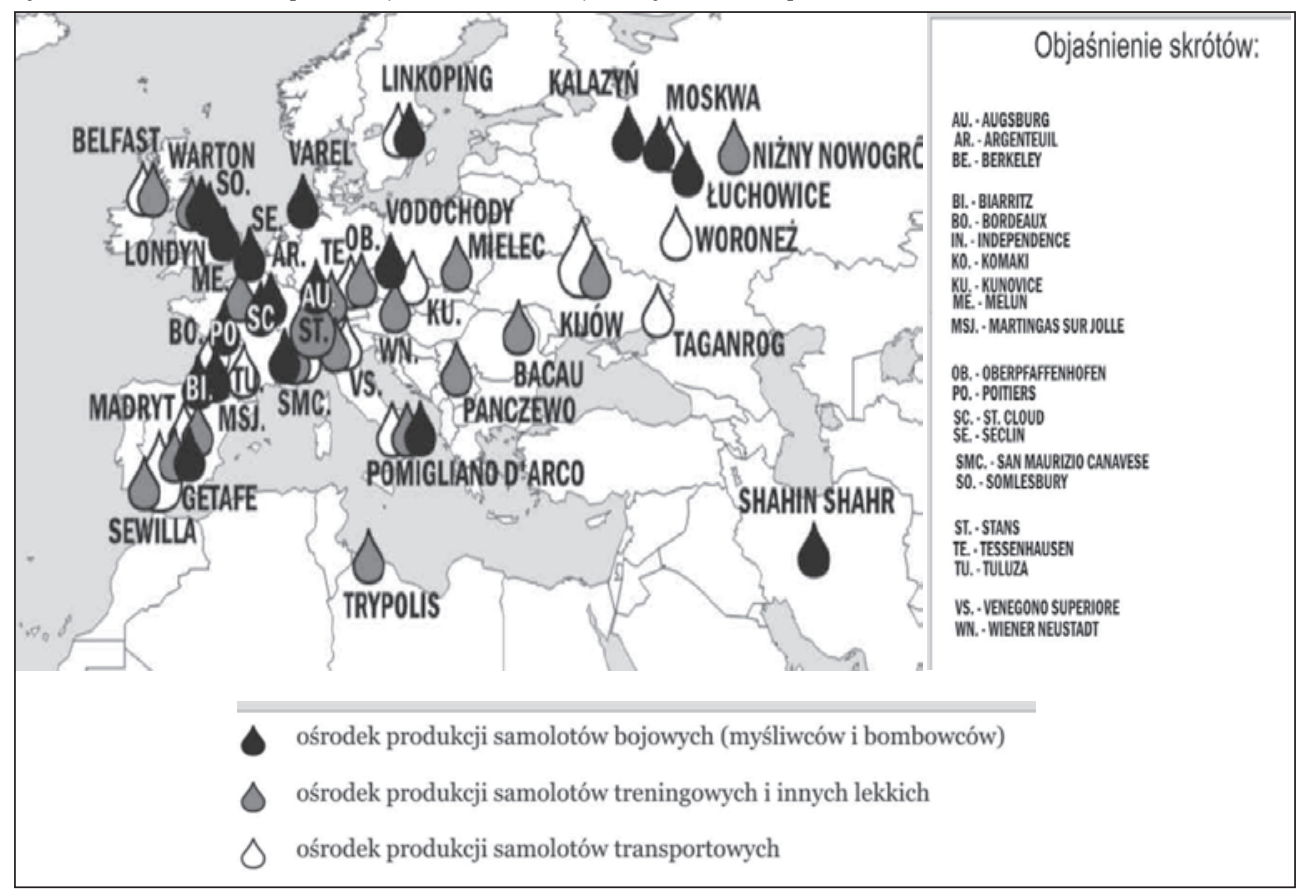

Źródło: opracowanie własne na podstawie danych SIPRI (2017, 17 stycznia)

Ryc. 8. Układ przestrzenny kompleksu zbrojeniowego Heckler\&Koch w Oberndorf am Neckar (2016)

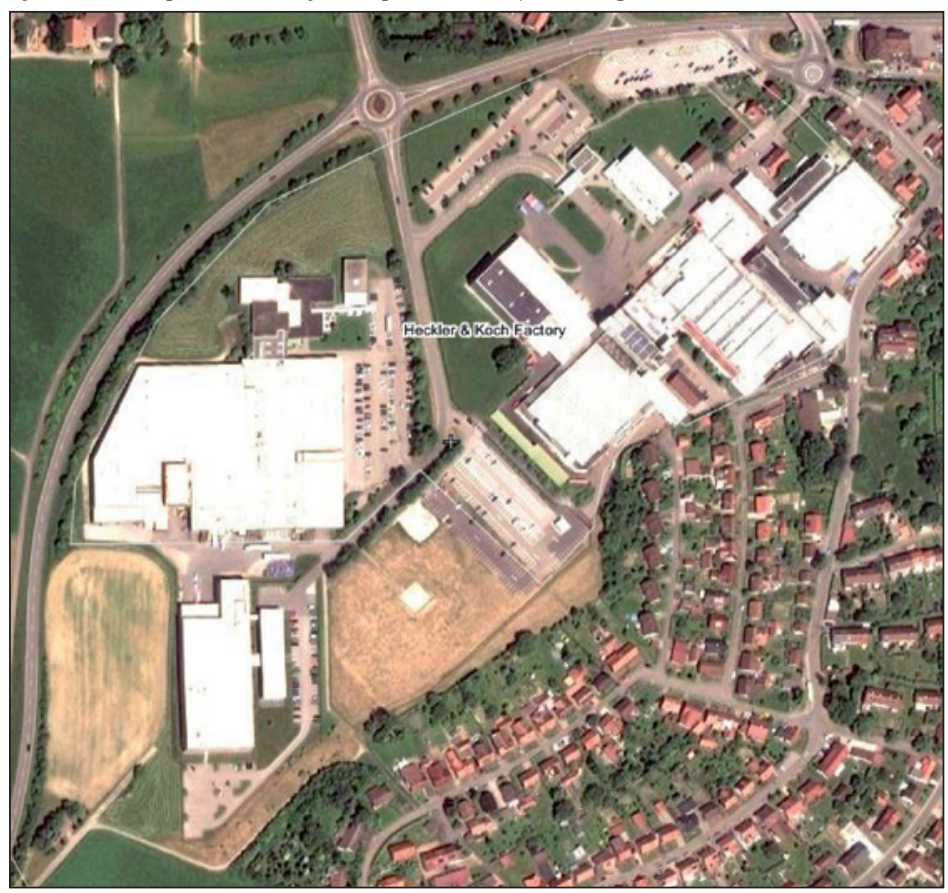

Źródło: wikimapia.org (2017, 17 stycznia) 
Ryc. 9. Układ przestrzenny kompleksu zbrojeniowego Rheinmetall Defense w Unterluess (2016)

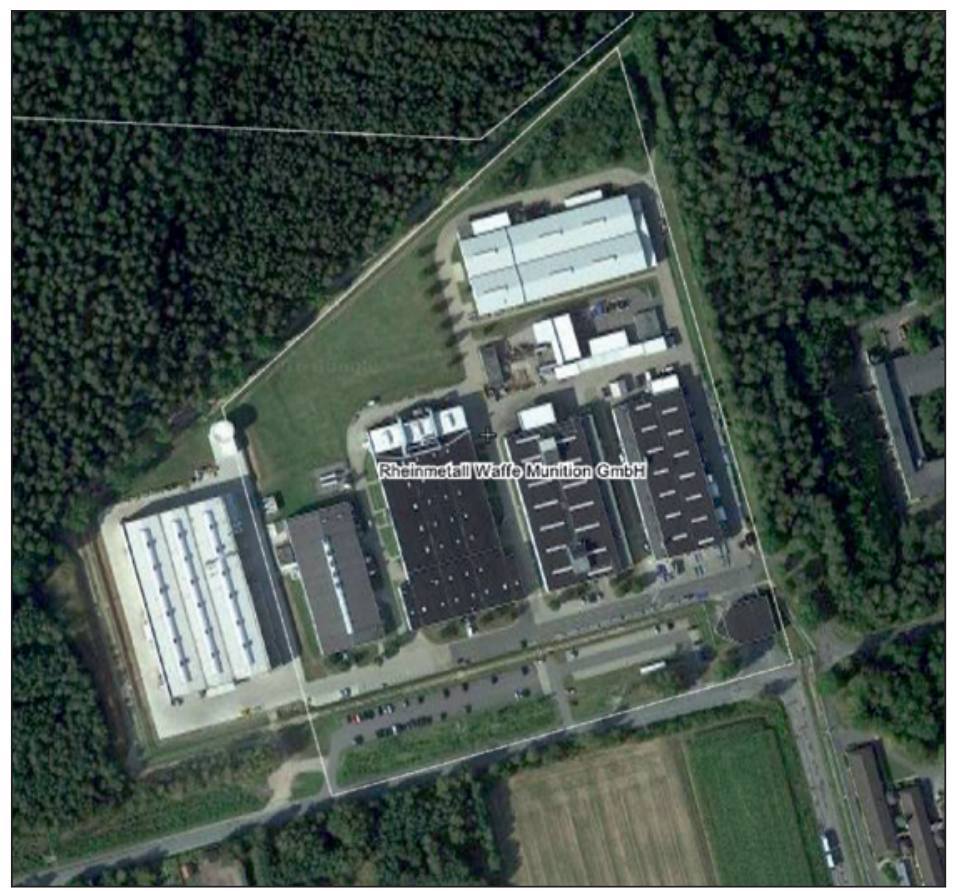

Źródło: wikimapia.org (2017, 17 stycznia)

wagony. Na północ między halą produkcyjną a bocznicą znajdują się jeszcze pomniejsze warsztaty i fabryka amunicji kal. 120 mm do czołgów Leopard 2. Na południe od hali produkcyjnej znajduje się parking, a nieco dalej obiekty wojskowe i szkoleniowe oraz instytut badawczy. Brama wjazdowa oraz obiekty ochrony są na zdjęciu satelitarnym zamaskowane w postaci „cienia”.

Największym producentem okrętów wojennych w Europie jest państwowe przedsiębiorstwo hiszpańskie - Navantia (2017, 17 stycznia). Posiada ona także stocznie w Chile i Australii. Budują one także statki na rynek cywilny, głównie o dużej wyporności. Jako spółka państwowa Navantia ściśle współpracuje z innymi stoczniami hiszpańskimi, położonymi w Kartagenie i San Fernando, niedaleko Kadyksu. Usytuowana w pobliżu bazy marynarki wojennej Hiszpanii w La Coruna, po drugiej stronie zatoki w mieście Ferrol, jako jedyny kompleks zbrojeniowy wymieniony w tym artykule nie posiada bezpośredniego połączenia z obiektami wojskowymi (ryc. 10).

Stocznia posiada trzy suche doki. W południowej części jest także nabrzeże wykorzystujące możliwość dostaw surowców i paliwa do okrętów drogą morską (brak jest bocznicy kolejowej). Przy tym nabrzeżu po zachodniej stronie stoczni znajdują się liczne magazyny i parkingi. Za nimi usytuowana jest największa hala produkcyjna, gdzie montowane są główne podzespoły okrętów, przerzucane następnie dźwigami nad doki. Największy dok jest najdalej na południe wysuniętą częścią stoczni. Otaczają ją place, dźwigi, a na północ od niej jest montownia części radioelektronicznych i biura. Dalej na wschód wzdłuż wybrzeża znajduje się stara część stoczni z dwoma mniejszymi dokami i wieloma warsztatami oraz biurem projektowym. Całość jest dobrze zabezpieczona od lądu. 
Ryc. 10. Układ przestrzenny kompleksu zbrojeniowego Navantia w Ferrol (2016)

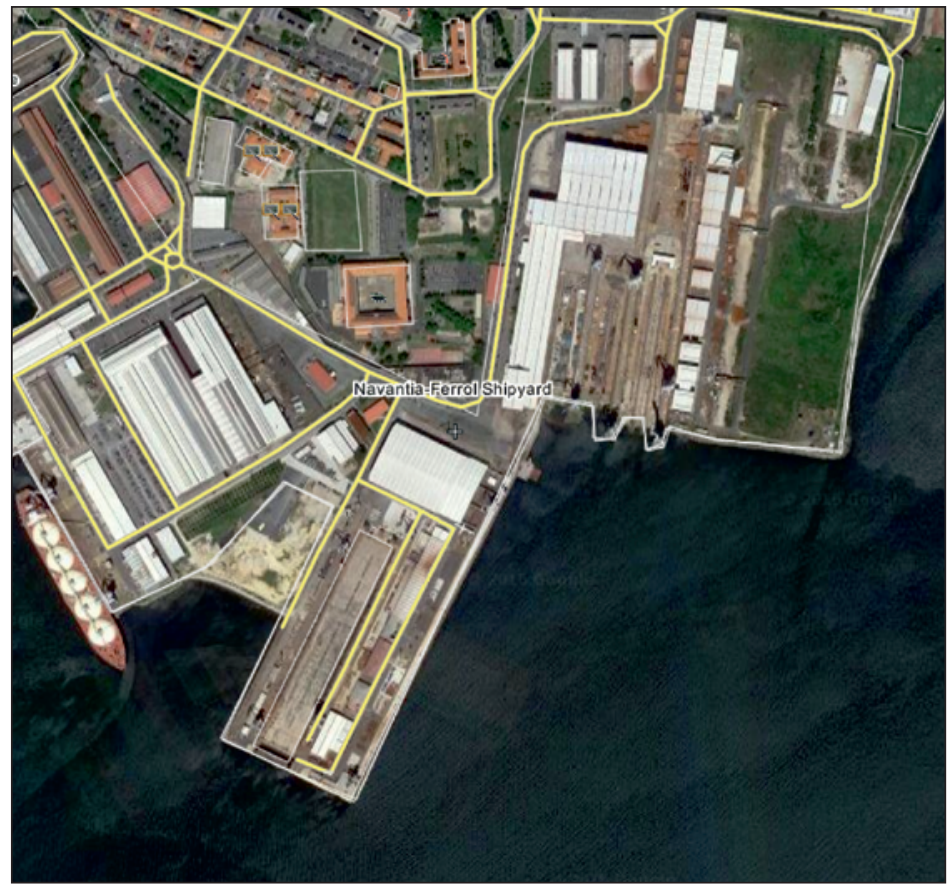

Źródło: wikimapia.org (2017, 17 stycznia)

Ryc. 11. Układ przestrzenny kompleksu zbrojeniowego BAE w Warton (2016)

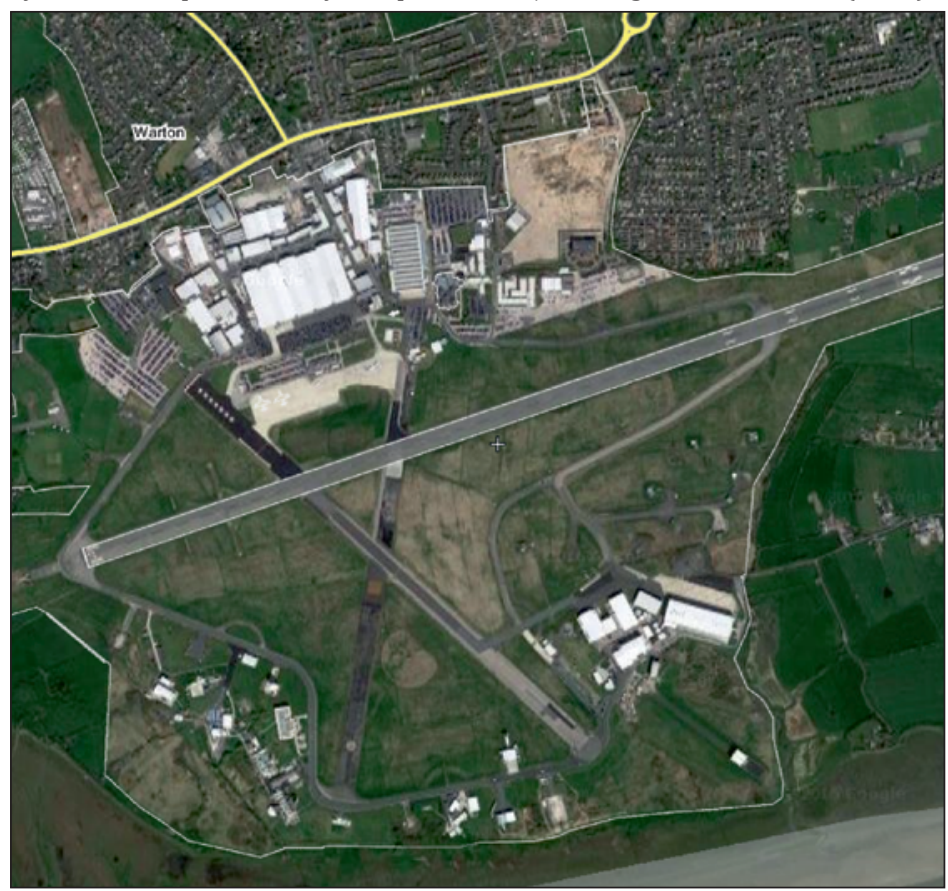

Źródło: wikimapia.org (2017, 17 stycznia) 
Największym producentem wojskowego sprzętu lotniczego w Europie jest brytyjskie przedsiębiorstwo BAE Air\&Information, będące częścią korporacji międzynarodowej BAE Systems (2017, 17 stycznia). Spółka ma siedzibę w Warton, w środkowej części Anglii. BAE Systems posiada wiele fabryk i zakładów na świecie, skupia się jednak najbardziej na działalności w Wielkiej Brytanii i Europie.

Główną oś kompleksu stanowi długi pas startowy. Na południe od niego znajdują się obiekty wojskowe i obiekty zabezpieczenia p-poż. Tam też składowana jest amunicja i bomby dla samolotów i tam od zachodniej strony dochodzi bocznica kolejowa. Centralnym punktem północnej części kompleksu jest główna hala produkcyjna. Wokół niej rozmieszczonych jest wiele pomniejszych warsztatów, magazynów, hal, biur, które oddzielają główną halę od bramy wjazdowej. Na wschód od hali znajduje się obiekt produkcji silników, drugi co do wielkości budynek, połączony z hangarami (ryc. 11).

\section{PODOBIEŃSTWA I RÓŻNICE W UKŁADACH PRZESTRZENNYCH KOMPLEKSÓW ZBROJENIOWYCH}

Analiza wybranych MIC pozwoliła na sporządzenie listy najczęściej występujących podobieństw i różnic pomiędzy nimi. Pierwszym rzucającym się w oczy podobieństwem jest położenie w małych miastach. Większość fabryk nie znajduje się w stolicach regionów, w których mogą być co najwyżej pojedyncze oddziały i przedstawicielstwa. Drugim podobieństwem jest bliskość kompleksów wojskowych (DIB - Defense Industrial Base), ale nie można stwierdzić, że zawsze jest to bezpośrednie sąsiedztwo (przypadek Navantii). Trzecim podobieństwem było dobre skomunikowanie drogowe, ale przede wszystkim kolejowe lub morskie. Dobre połączenie z infrastrukturą kolejową lub morską gwarantuje dostawę oraz odbiór towarów masowych, zarówno surowców, jak i broni, której dostawy zwykle są znaczne. Czwartym podobieństwem jest szczególne uwzględnienie w zagospodarowaniu potrzeby zapewnienia wysokiego poziomu bezpieczeństwa, co najbardziej uwidocznione było w przypadku fabryki Rheinmetall, gdzie bramę wjazdową i stanowiska strażników zamaskowano na zdjęciu satelitarnym. Stąd też piąte podobieństwo - ograniczony dostęp do obiektów (zwykle tak jak w Polsce wymagana jest przepustka, wystawiana po sprawdzeniu ubiegającego się przez odpowiednie służby) oraz informacji (brak detali na stronach internetowych) (Żebrowski, 2016). Szóstym podobieństwem jest budowanie obiektów zbrojeniowych na terenie płaskim, nieotoczonym wzniesieniami, z których można by było bezpośrednio obserwować, co dzieje się na terenie zakładów. Siódmym podobieństwem jest bliskość ośrodków akademickich. Są to w przypadku H\&K - Heidelberg, Rheinmetall - Getynga i Kassel, Navantii - La Coruna i w przypadku BAE - Liverpool i Manchester (Soroka, 2016). Ósmym podobieństwem, z jakim można było się spotkać, jest pochodzenie wszystkich korporacji z okresu zimnowojennego. To wtedy najwięcej zarabiały i przejmowały inne fabryki zbrojeniowe z okresu drugiej wojny światowej, które wcześniej z nimi konkurowały. Proces ten nasilił się w okresie kryzysu. Dziewiątym podobieństwem, jakie wykazano, jest dość prosta struktura własności największych korporacji zbrojeniowych, lecz skomplikowana i nie zawsze jawna struktura wewnętrzna przedsiębiorstw i powiązania z wojskiem i strukturami rządowymi. Po dziesiąte, każdy z kompleksów z oczywistych względów zajmuje całkiem spory obszar, niekiedy mający znaczny udział w ogólnej powierzchni miasteczka, w którym funkcjonuje. Wiele z korporacji zatrudnia również ponad kilka tysięcy pracowników, co zwykle zalicza je 
do wielkich przedsiębiorstw i znacznych pracodawców - to jest ostatnim, jedenastym wyróżnionym podobieństwem.

Różnica pomiędzy poszczególnymi MIC dotyczy głównie, z oczywistych względów, charakteru i środowiska produkcji. Wpływa to też na układy przestrzenne tych kompleksów. Druga różnica, która da się zauważyć pomiędzy MIC, to zróżnicowane powiązania z innymi kompleksami, w zależności od państwa. W niektórych są dopuszczalne powiązania międzynarodowe, $\mathrm{w}$ innych tylko sojusznicze, jeszcze $\mathrm{w}$ innych tylko wewnątrzkrajowe. Trzecią różnicą, z jaką się spotkano, analizując temat, jest rodzaj własności. Występują trzy rodzaje: wielkie korporacje międzynarodowe (np. Rheinmetall, BAE), mniejsze prywatne korporacje ukierunkowane nie tylko na produkcję zbrojeniową (H\&K), a także przedsiębiorstwa skarbu państwa (Navantia) (Cimek, 2012). Powyżej wskazano również czwartą różnicę. Jest nią wysokość udziałów w produkcji danego kompleksu na potrzeby rynku cywilnego. Może być on dość wysoki (H\&K, Navantia), mocno ograniczony (BAE) lub całkowicie zabroniony (Rheinmetall Defense). Oczywistą piątą różnicą jest także asortyment produkowanej broni. Są przedsiębiorstwa, które skupiają się wyłącznie na swojej gałęzi produkcji zbrojeniowej $(\mathrm{H} \& \mathrm{~K})$, takie, które dobierają sobie dodatkową gałąź, którą wykorzystują w głównej produkcji (Navantia - produkcja elektroniki i rakiet oraz torped), lub takie, które mają bardzo szerokie spektrum produkcji, a wskazana w artykule jest jedną z wielu (BAE, Rheinmetall). Ze stron internetowych można wnieść także jeszcze szóstą różnicę. Wpływ, jaki chce wywoływać dane przedsiębiorstwo na społeczność lokalną, jest wyraźnie zróżnicowany. Niektóre przedsiębiorstwa (jak H\&K) aktywnie uczestniczą w działalności kulturalnej i władz samorządowych i są w te działania zaangażowane. Inne robią to $\mathrm{w}$ bardzo ograniczonym zakresie (BAE), a jeszcze innych takie wsparcie w ogóle nie interesuje (Rheinmetall, Navantia). Porównując różne spółki tworzące MIC, da się wyraźnie zauważyć dysproporcje w zaawansowaniu technologicznym i inwestycjach w sektor R\&D pomiędzy głównymi mocarstwami a państwami mniejszymi, szczególnie po dawnej wschodniej stronie układów zimnowojennych. Jest to już siódmą różnicą. Ósma dotyczy wielkości przedsiębiorstw tworzących MIC. Nie zawsze MIC są wielkie, gdyż mogą być, jak w przypadku Rheinmetall, rozbite na wiele zakładów rozsianych po kraju. Często ogólna wielkość MIC w poszczególnych krajach jest prawie wprost proporcjonalna do wielkości uśrednionych wieloletnich nakładów na zbrojenia danego państwa. Dziewiąta różnica dotyczy polityki poszczególnych państw wobec MIC. W niektórych państwach ta forma współpracy w sektorze jest nadal promowana, w innych stopniowo się od niej odchodzi na rzecz formuły przetargów. Dziesiąta różnica również jest uzależniona od państwa. Zauważono znaczne różnice u poszczególnych państw w finansowaniu badań nad przyszłym uzbrojeniem. W niektórych państwach wszystkie badania są uzależnione od nakładów państwowych (np. Polska), w innych ma to spore znaczenie, jednak firmy starają się tak generować zyski, by nie zależeć od nakładów państwowych (np. Hiszpania), a w innych wszystkie inwestycje są w rękach prywatnych (np. Szwajcaria). Ostatnią - jedenastą - wyróżnioną różnicą jest sposób restrukturyzacji i historia poszczególnych MIC po zakończeniu rywalizacji zimnowojennej. Drogi tej restrukturyzacji jeszcze bardziej się różnicowały w okresie kryzysu finansowego rozpoczętego w 2007 roku. 


\section{ZAKOŃCZENIE}

W zakończeniu postanowiono odpowiedzieć na pytanie, czy rozwój polskiego przemysłu zbrojeniowego jest $\mathrm{w}$ jakiś sposób blokowany uwarunkowaniami geograficznymi lub przestrzennymi. W Polsce istnieje kilka aktywnych MIC. Znajdują się one w Tarnowie, Siemianowicach Śląskich, Radomiu, Kutnie, Mielcu, Gdyni, a kilka mniejszych w innych miastach (Jaworski, 2006). Przyglądając się ich położeniu i wytworzonym przez lata powiązaniom układów przestrzennych, wydaje się, że jedynie zakłady w Siemianowicach Śląskich mogą mieć w przyszłości problem z rozwojem terytorialnym swego kompleksu. Można jednak tę produkcje przenieść w inne miejsce, więc nie stanowi to ostatecznie przeszkody dla rozwoju przemysłu zbrojeniowego w Polsce.

Konkludując zatem, należy stwierdzić, że rozwój polskiego przemysłu zbrojeniowego jest raczej blokowany przez inne niż wymieniono czynniki. To, że jego kondycja jest ogólnie mało konkurencyjna na rynku europejskim (Maśloch, 2013; Gajda, 2015), pokazały ryciny zamieszczone $\mathrm{w}$ artykule. Powolna agonia polskiego sektora zbrojeniowego to wynik ogólnej słabej kondycji gospodarczej państwa, układów politycznych oraz niezharmonizowanych przepisów prawnych.

\section{Bibliografia \\ References}

Albertson, D. (ed.) (1963). Eisenhower as President. New York: Hill and Wang.

BAE Systems $(2017,17$ stycznia). Pozyskano z www.baesystems.com

Balcerowicz, B. (2006). Siły zbrojne w państwie i stosunkach międzynarodowych. Warszawa: Scholar.

Cimek, G. (2012). Korporacje ponadnarodowe na globalnej szachownicy. Historia i Polityka, $8(15), 45-61$.

Dunne, J.P. (1995). The Defence Industrial Base. W: Keith Hartley \& Todd Sandler (eds.). Handbook in Defense Economics. Amsterdam: Elsevier, 592-623.

Fine, B. (1993). The military industrial complex: An analytical assessment. Cyprus Journal of Economics, 6(1), 26-51.

Freedman, L.D. (2014). Torpedo: inventing the military-industrial complex in the United States and Great Britain. Foreign Affairs, 93(3), 181-182.

Furgacz, P. (2015). Europejski przemysł zbrojeniowy w XXI wieku. W: T.Z. Leszczyński (red.). Bezpieczeństwo Europy. Kontekst gospodarczy. Kraków: Polskie Towarzystwo Geograficzne, $40-60$

Gajda, W. (2015). Innowacyjność polskiego przemysłu na tle przemysłu światowego. Prace Komisji Geografii Przemysłu Polskiego Towarzystwa Geograficznego, 29(1), 42-55.

Harris, S. (2014). @ War: The Rise of the Military-Internet Complex. Boston: Houghton Mifflin Harcourt.

Hartley, K., Sandler, T. (eds.) (1995). Handbook of Defense Economics. Vol. 1. Amsterdam: Elsevier.

Heckler\&Koch (2017, 17 stycznia). Pozyskano z www.heckler-koch.com

Hercik, J., Szczyrba, Z. (2012). Post-military areas as space for business opportunities and innovation. Prace Komisji Geografii Przemysłu Polskiego Towarzystwa Geograficznego, 19, 142-152.

Holota, M., Kurpas, M. (2016). Kryteria i zasady projektowania współczesnych pojazdów bojowych z uzbrojeniem wielkokalibrowym. Część 1. Szybkobieżne Pojazdy Gq̨ienicowe, 1(39), $15-38$.

Jankowski, D.P. (2011). Planowana reforma Bundeswehry i jej wpływ na niemiecki przemysł zbrojeniowy. Zeszyty Naukowe AON, 1(82), 320-327.

Jaworski, J. (2006). Restrukturyzacja polskiego przemysłu zbrojeniowego. Prace Komisji Geografii Przemysłu Polskiego Towarzystwa Geograficznego, 9, 130-142. 
Lovering, J. (1990). Military expenditure and the restructuring of capitalism: The military industry in Britain. Cambridge Journal of Economics, 14(4), 453-468.

Maśloch, G. (2013). Przedsiębiorstwa paneuropejskie wobec konsolidacji, fuzji i przejęć a gospodarka Polski: szansa czy wykluczenie z gry o rozwój? Prace Komisji Geografii Przemysłu Polskiego Towarzystwa Geograficznego, 21, 212-224.

Navantia (2017, 17 stycznia). Pozyskano z www.navantia.es

Rheinmetall $(2017,17$ stycznia). Pozyskano z www.rheinmetall-defence.com

SIPRI (2017, 17 stycznia). Sztokholmski Instytut Badań nad Pokojem. Pozyskano z www.sipri.org

Smith, R. (1977). Military expenditure and capitalism, Cambridge Journal of Economics, 1, 61-76.

Soroka, P. (2016). Rola nowoczesnych technologii w wyścigu zbrojeń. Przegląd Geopolityczny, 16, 77-86.

Wikimapia (2017, 17 stycznia). Pozyskano z www.wikimapia.org

Wilczyński, P.L. (2012). Innowacje w zbrojeniach i obronności jako katalizator przemian technologicznych. Prace Komisji Geografii Przemysłu Polskiego Towarzystwa Geograficznego, 20, 124-133.

Wilczyński, P.L. (2013a). Sektor zbrojeniowy jako czynnik rozwoju gospodarki opartej na wiedzy. Prace Komisji Geografii Przemysłu Polskiego Towarzystwa Geograficznego, 21, 133-156.

Wilczyński, P.L. (2013b). Inwestycje w zbrojenia w czasach kryzysu. Przedsiębiorczość - Edukacja, 9, 227-243.

Wilczyński, P.L. (2015a) (2017, 17 stycznia). Nie tylko koncerny, czyli kto może zarobić na zbrojeniach. Polska Zbrojna, 9. Pozyskano z http://wiadomosci.wp.pl/nie-tylko-koncerny-czyli-kto-moze-zarobic-na-zbrojeniach-6027693333693057a

Wilczyński, P.L. (2015b). Produkcja wojskowej broni strzeleckiej w Europie. W: T.Z. Leszczyński (red.). Bezpieczeństwo Europy. Kontekst gospodarczy. Kraków: Polskie Towarzystwo Geograficzne, 61-72.

Wilczyński, P.L. (2015c). Rozmieszczenie europejskich stoczni produkujących okręty wojenne. Prace Komisji Geografii Przemysłu Polskiego Towarzystwa Geograficznego, 29, 138-161.

Wilczyński, P.L. (2016). Geografia europejskiego przemysłu motoryzacyjnego w branży zbrojeniowej. W: R. Kopeć (red.). Przemysł zbrojeniowy - tendencje, perspektywy, uwarunkowania, innowacje. Kraków: Wydawnictwo Naukowe Uniwersytetu Pedagogicznego, 149-176.

Woźniak, R. (red.) (2001-2002). Encyklopedia najnowszej broni palnej. Tomy 1-4. Warszawa: Bellona.

Żebrowski, A. (2016). Zagrożenia i bezpieczeństwo przemysłu zbrojeniowego u progu XXI wieku (wybrane aspekty). W: R. Kopeć (red.). Przemysł zbrojeniowy-tendencje, perspektywy, uwarunkowania, innowacje. Kraków: Wydawnictwo Naukowe Uniwersytetu Pedagogicznego, 8-71.

Żukrowska, K. (1989). Broń na sprzedaż: kompleks militarno-przemysłowy a zbrojenia. Warszawa: Wydawnictwo Ministerstwa Obrony Narodowej.

Piotr L. Wilczyński, dr, prezes Polskiego Towarzystwa Geopolitycznego, badacz tematyki geopolitycznej, także z zakresu geografii wojskowej i wojennej oraz geostrategii. Autor wielu publikacji naukowych, map i artykułów publicystycznych. Uważany za eksperta w zakresie bezpieczeństwa międzynarodowego dzięki współpracy z wojskiem i innymi służbami mundurowymi w zakresie szkoleń. Znawca uzbrojenia i nowoczesnych technologii zbrojeniowych, a także rynku obrotu uzbrojeniem zarówno dla sił lądowych, jak i marynarki oraz lotnictwa.

Piotr L. Wilczyński, Ph.D., chairman of the Polish Geopolitical Society, researcher of such subjects as geopolitics, military geography, military conflicts, geostrategy. Author of many scholarly publications, maps and articles in popular papers. Considered an expert of international security. Cooperates with military sector as well as other public service institutions as an instructor and lecturer. He has deep knowledge on military equipment, technologies, and armaments markets in land forces, navy and military aviation.

\section{Adres/address:}

Uniwersytet Pedagogiczny w Krakowie

Zakład Geografii Społeczno-Ekonomicznej

ul. Podchorążych 2, 30-084 Kraków, Polska

e-mail: Piotr.Wilczynski@up.krakow.pl 